\title{
GEOGRAFSKA PROBLEMATIKA OBMEJNEGA NASELJA DVORI PRI MOVRAŽU
}

\author{
Valentina Brečko Grubar*
}

\begin{abstract}
Izvleček
Naselje Dvori leži $v$ neposredni bližini slovensko-hrvaške meje, nad mejnim prehodom Sočerga in hrvaškim naseljem Mlini. Bližnje oskrbno naselje je $12 \mathrm{~km}$ oddaljeno Gračišče, kjer so osnovna šola, ambulanta, krajevni urad, pošta, bencinski servis, dve trgovini in gostilna. Cestna povezava poteka od Gračišča skozi naselji Smokvica in Movraž, nekdanja povezava z Mlini je zaradi državne meje prekinjena, do železniške postaje Rakitovec (železniški mejni prehod na progi proti Puli) pa vodi strma makedamska cesta. Od Kopra so Dvori oddaljeni več kot 20 km, zato so bili v preteklosti boli povezani z bližjim Buzetom. Razmere so se $v$ marsičem spremenile, kar pa ni le posledica nastanka meje, ampak predvsem socialnih sprememb. Nekdai je bilo kmetijstvo, kliub mani ugodnim pogojem, glavni vir dohodka prebivalcev, danes pa obsežne pašne površine in senožeti prerašča gospodarsko nepomemben gozd. Za naselje je poleg stalnega upadanja števila prebivalcev značilna tudi prevlada ostarelih gospodinjstev, ki so brez naslednikov. Nastanek državne meje in s tem obmejna lega za življenje prebivalcev nista imela večjih negativnih posledic. Prekomejno lastništvo se tu pojavlia $v$ zelo majhnem obsegu in zadeva le hrvaške prebivalce, zaposlovanje na hrvaški strani meje je bilo izjema že pred letom 1991, sorodstvene vezi pa so se kljub nastanku meje ohranile.
\end{abstract}

Ključne besede: depopulacija, zaraščanje, Dvori, movraška vala

\section{GEOGRAPHY OF BORDER SETTLEMENT DVORI NEAR MOVRAŽ}

\begin{abstract}
Settlement Dvori is situated in the closest vicinity of the Slovene-Croatian border above the cross point Sočerga and the Croatian settlement Mlini. The nearest supply centre is Gračišče from which the settlement is $12 \mathrm{~km}$ far off and from
\end{abstract}

"Mag., asist., Oddelek za geografijo, Filozofska fakulteta, Aškerčeva 2, 1000 Liubljana, Slovenija 
Koper it is more than $20 \mathrm{~km}$ far off. Former road connection with Mlini is disconnected due to the state border and a steep macamade road is leading to the railway station Rakitovec (railway cross point at the railway track to Pula). The inhabitants of the settlement Dvori were in the past more connected with Buzet, which is $7 \mathrm{~km}$ far off than with Koper, but nowadays they are depending on Koper from the employment as well as from the supply point of view. The settlement is characterised by permanent decrease of the number of inhabitants as well as by increasing number of aged households with no successors and abandonment of agriculture, resulting in overgrowing of cultural land. Living of the inhabitants was not influenced negatively by establishment of the state border and consecutive border position. Over-border propriety is of concern only for the Croatian inhabitants, employment and supply on the Croatian borderline was not usual also before 1991, but the connections among relatives are still strong.

Key words: depopulation, overgrowing, Dvori, movraška vala

\section{Lega naselja}

Dvori ležijo na skrajnem jugovzhodnem delu slavniškega pogorja, ki je nadaljevanje Čičarije, oz. na prehodu iz te apnenčaste hribovite pokrajinske enote, pogosto poimenovane Bela Istra, v flišno Sivo Istro. Prehod predstavlja niz gub in narivnih plasti tektonskega nastanka, ki se $\vee$ pokrajini kažejo kot izrazite skalne stopnje, imenovane stene, ki so pogosto celo previsne oz. oblikovane kot spodmoli (Kunaver, Ogrin, 1993). Pohodnikom in plezalcem so dobro poznane stene pod Velim Badinom, južno od naselja, ki so vidne tudi s ceste Sočerga-Buzet takoj po prestopu meje. Apnenčaste hrbte z nadmorsko višino od 400 do 500 m ločuje več, v smeri SZ-JV potekajočih suhih dolin oz. val. Večinoma so poimenovane po naseljih, katerih prebivalci so tudi lastniki zemliišč (gračiška, lukinska, smokavska, movraška itd.). Dvori ležijo na jugovzhodnem robu movraške vale, približno $3 \mathrm{~km}$ dolge in $500 \mathrm{~m}$ široke doline na nadmorski višini 180 do 200 m, ki jo na severovzhodu obdajajo strma pobočja Kuka, Grebena in Stražnice (450 do 500 m nmv), na jugozahodu pa nižja in položnejša pobočja Velega Badina, Sv. Kvirika 
Slika 1: Lega Dvorov na robu movraške vale (Geodetska uprava RS)

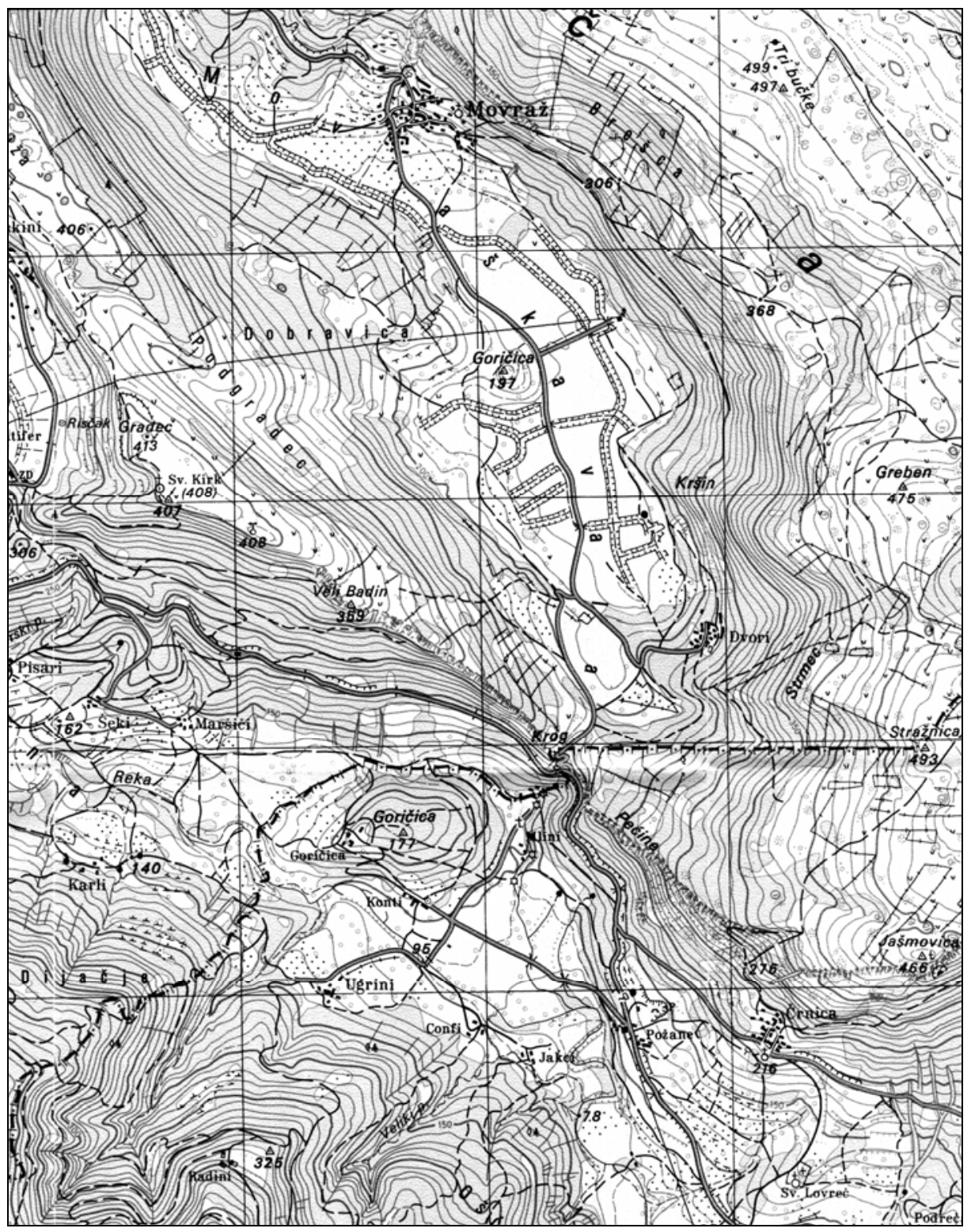


(Kikirika, Kirka) in Vele Griže (okoli 400 m nmv). Naselje leži nekaj deset metrov nad dnom vale, kar je pomembno zaradi občasne poplavljenosti in zadrževanja hladnega zraka ob temperaturnih inverzijah, ter $v$ zavetrni legi, zavarovani pred burjo.

Gručasto naselje naj bi nastalo pred približno 400 leti iz prvotnih pastirskih bivališč in hlevov, postavljenih ob vznožju pašnih pobočij, ki so segala do slemena med Rakitovcem in movraško valo. Staje oz. dvori naj bi dali naselju tudi ime.

\section{Prebivalstvo}

Dvori so po številu prebivalcev $v$ nizu naselij od Gračišča do meje $s$ Hrvaško najmanjše naselje, nekoliko manjše od Smokvice in mnogo manjše od sosednjega Movraža. V vseh treh naseljih skupaj je v začetku 20. stoletja živelo nad 760 prebivalcev, stoletje kasneje pa le še 160. Ob vseh popisih prebivalstva $v$ tem obdobju so prebivalci Dvorov predstavljali dobro desetino skupnega števila. Leta 1910 je na Dvorih živelo 87 prebivalcev, po drugi svetovni vojni 66, do leta 1961 se je število zmanjšalo na 36 in do leta 2000 na 21 (Krajevni..., 1995). V vsem obdobju torej beležimo upadanje števila prebivalcev, ki je bilo do 50. let pretežno odraz manjšega naravnega prirastka in dveh svetovnih vojn, $v$ manjši meri pa tudi izselitev. Bistveno zmanjšanje oz. prepolovitev prebivalstva $\vee$ mani kot desetih letih se je zgodilo pred letom 1961 in je bilo deloma posledica t. i. "bega z dežele", v tem primeru bega na obalo ali v njeno bližino, deloma pa nasledstva brez potomcev. Nastanek meje med cono B Svobodnega tržaškega ozemlia in Jugoslavijo v letih 1947-1954, ko so Dvori, tako kot še vrsta naselij v notranjosti Slovenske Istre, ostali odrezani od Trsta, ni povzročil odseljevanja, ker prebivalci niso bili odvisni od zaslužka preko meje. Po letu 1954 je odseljevanje vzpodbudil gospodarski in družbeni razvoj obalnega območja, ki je omogočil boljše pogoje za življenje kot prenaseljeno podeželje. Zaradi zaposlitve so se izselili predvsem mlajši moški, ženske pa so se že tradicionalno izseljevale zaradi porok. Tisti, ki so ostali doma in so po smrti staršev postali gospodarii, ne pa vedno tudi lastniki posesti, se $v$ več primerih niso poročili ali pa niso imeli potomcev. Posledice nastalih razmer se danes kažejo $v$ več praznih domovih in $v$ staranju gospodinjstev. Slednje pa se odraža tudi $v$ pomanjkliivem vzdrževanju stavbnega sklada ter $v$ zaraščanju kulturne pokrajine. Današnje število prebivalcev predstavlja le četrtino od zabeleženega največjega števila in od 
15. domov je stalno naseljenih le 7. Štiri gospodinistva so brez naslednikov in ostarela, $v$ dveh živijo skupaj starši in že odrasli otroci ter $v$ enem tri generacije. $\checkmark$ naselju ni šoloobveznega otroka in le eden je predšolski. Leta 1991 je bil delež aktivnega prebivalstva $24 \%$, danes pa delež presega $60 \%$. Sprememba je posledica zaposlitve leta 1991 še šolajočih se mlajših prebivalcev, skupno število prebivalcev pa se je zaradi umiranja tudi zmanišalo. Od 14 aktivnih prebivalcev leta 2000 ima večina končano le osnovno ali poklicno srednjo šolo, dva pa visoko. Statistični podatki nekoliko odstopajo od dejanskega stanja, ki je še mani ugodno. Na Dvorih imajo namreč stalno bivališče tri (mlajše in zaposlene) osebe, ki so tu le ob koncu tedna, dve (starejši in upokojeni) pa imata stalno bivališče $v$ Kopru in živita na Dvorih. Od stalno živečih 20 prebivalcev je 12 moških in 8 žensk, starejših od 50 let je 12 oseb, dve osebi sta starejši od 65 let oz. najstarejša ima 90 let.

\section{Raba zemljišč in viri dohodkov prebivalstva}

Do druge svetovne vojne je bil glavni vir dohodkov večine gospodinjstev na Dvorih kmetijstvo, ki je skupaj s priložnostnimi zaposlitvami omogočalo skromno življenje številčno velikih družin. Pogoji za kmetovanje so v movraški vali in na pobočjih, ki jo obdajajo, razmeroma neugodni. Nekdaj so bila kraška pobočja severno od vasi, domačini uporabljajo ime Kras, na topografski karti sta navedeni imeni Strmec in Kršin, namenjena paši. Na vršnem slemenu Grebena so v večjih vrtačah uredili njive za pridelavo krompirja, ob vznožju pobočja blizu domov so s terasami pridobili površine za pridelavo zgodnjih pomladnih in zimskih povrtnin, še danes se zanje uporablia ime vrt, ravne površine $v$ vali pa so bile namenjene pridelavi žita in različnih kultur za prehrano in krmo.

Takšno kmetijstvo je zahtevalo veliko ročnega dela, pomanjkliivo gnojenje in neugodni naravni pogoji pa so pogosto omogočili zelo skromno pridelavo. Glede naravno mani ugodnih razmer za kmetovanje $v$ movraški vali so v ospredju podnebne značilnosti (Ogrin, 1995), zlasti pomanjkanje padavin $v$ rastni dobi in pomladne pozebe. Prst je $v$ vali in na zahodnem pobočju sicer globoka, vendar glineno-ilovnata in težka za obdelovanje, na vzhodnem pobočju pa plitva rjava z veliko skeletnimi delci. Obdelovalne površine $v$ dnu vale ogrožajo tudi vsakoletne poplave, ki nastopijo po obilnejših padavinah v hribovitem svetu Čičarije. 
Vode s kraškega zaledja movraške vale se podzemno pretakajo proti porečju Bračane, to je desni pritok Mirne, in izvirajo pod steno nad zaselkom Mlini. Ob zelo visokih stanjih pa kot izviri delujejo tudi estavele $v$ dnu vale, ena je $\vee$ njenem jugovzhodnem delu pod Dvori, ki sicer odvajajo občasne površinske vode z movraške vale in njenega jugozahodnega pobočja. Da bi pospešili odtekanje vode in zmanjšali mokrotnost zemljišč, so bile konec 70. in $\checkmark$ začetku 80. let izvedene melioracije. Izkopani so bili drenažni jarki, s kamni utrjene brežine glavnih odvodnikov, odstranjena je bila večina dreves (ostanki velikih topolov še danes propadajo ob cesti) in zemljišča globoko preorana. Načrtovana komasacija ni bila izvedena, meje "starih" parcel so bile uničene in domačini so jih sporazumno približno določili. Interes za obdelovanje in $\mathrm{s}$ tem potreba po zemljiščih sta bila takrat že $v$ upadanju, zato melioracije niso kaj dosti pripomogle h kmetijski pridelavi. Današnji pomen kmetovanja pa je $\checkmark$ gospodarskem pogledu zanemarljiv, saj je večinoma namenjeno samooskrbi. Njivske površine imajo zelo skromen obseg, večino nekdaj ornih površin pokrivajo travniki, in še ti se vedno boli zaraščajo. Pašnike, senožeti in manjše "krpe" obdelovalnih površin pa je že davno zajel proces ogozdovanja.

Večina obdelovalnih površin je na položnejšem zahodnem pobočju in $v$ dnu vale. Na voljo je veliko zemljišč in tri gospodarstva, ki še imajo živino, eno redi govedo in prodaja mleko, vsa tri pa redijo prašiče za lastne potrebe, obdelujejo najkvalitetnejše površine. Z združevanjem svojih parcel s parcelami sosedov so nastala večja in za strojno obdelovanje primernejša zemliišča. $\mathrm{Na}$ ornih površinah prevladuje žito in $v$ manjši meri okopavine. Od trajnih nasadov lahko omenimo le trto, ki porašča višje, proti vzhodu orientirane lege, okoli domov so sadna drevesa, oljk in mandljevcev pa zaradi pogostih pozeb skorajda ni.

Danes sta poglavitna vira dohodkov prebivalcev zaposlitev, pretežno v terciarnih dejavnostih, in pokojnine. Po podatkih za leto 1991 je bilo $v$ sekundarnih dejavnostih zaposlenih 33,3 \% in v terciarnih dejavnostih 66,7 \% aktivnega prebivalstva. Od terciarnih dejavnosti izrazito prevladujeta komunala in trgovina. Delež zaposlenih dnevnih migrantov je bil 100 \% (Krajevni..., 1995). Zdaj se dnevno vozi na delo v Koper devet prebivalcev, med katerimi prevladujejo moški, in $v$ Trst tri ženske, ki so uradno nezaposlene. Šest prebivalcev je upokojenih. Delo $v$ Trstu pomembno prispeva $k$ družinskemu proračunu treh gospodinjstev, dopolnilni vir enega pa so še storitve s težko mehanizacijo (zemeljska dela). Drugih dejarnosti v naselju ni. 


\section{Kakovost bivalnega okolja}

Pogoji za življenje so zaradi boljše prometne povezanosti, vsaj delne komunalne opremljenosti in možnosti dodatnega zaslužka boliše kot $v$ preteklosti. Naselje ima lastni vodovod, ki se oskrbuje iz zajetega kraškega izvira $v$ pobočju nad vasjo, vode pa $v$ poletju in zgodnji jeseni primanjkuje. Dovažajo jo iz rižanskega vodovoda, ki sega do sosednje vasi Movraž. Kanalizacijsko omrežje ni zgrajeno in odpadne vode iz pretočnih greznic prenikajo $\vee$ tla, od tam pa $\vee$ izvire nad Mlini. Dvori žal ne ležijo $\vee$ vodovarstvenem območju zajetii za rižanski vodovod, tako kot Movraž, zato izgradnja kanalizacije in čistilne naprave ni bila obvezna. Električna napeljava je iz začetka 50. let in večje dodatne obremenitve brez obnove niso možne. Odvoz odpadkov je urejen, telefonska povezava je vzpostavljena, delovanje mobilnih telefonov pa je moteno. Avtobusnih zvez je malo, od štirih pa bosta verjetno še dve ukinjeni, ker $v$ vasi ni šoloobveznih otrok. Samo dve gospodinjstvi sta brez avtomobila in odvisni od javnega prevoza, večina drugih pa ima več kot en avto. To je zaradi različnega delovnega časa zaposlenih in najmani 7 kilometrov oddaljenih oskrbnih dejavnosti skoraj nujno potrebno. Cesta, ki povezuje Dvore, Movraž in Smokvico z Gračiščem, je asfaltirana, vendar zelo ozka, v movraški vali pa je občasno tudi poplavljena. Ker je nekdanja povezava z Mlini zaradi meje prekinjena, je naselje ob velikih poplavah nedostopno. Izgradnja cestne povezave zunai poplavnega območja je načrtovana že od leta 1991. Stanovanjska površina na prebivalca je zaradi manjšega števila članov gospodinjstev precej večja kot $v$ preteklosti, opremljenost pa je večinoma skromna in ogrevana je le kuhinja oz. kuhinja in dnevni prostor. Dve nadomestni stanovanjski gradnji sta že starejši, ena stanovanjska hiša je novozgrajena, vsaj deloma obnovljene pa so štiri, od tega tri kot počitniška bivališča.

\section{Zaključek}

Zaradi neugodne prebivalstvene sestave tudi $v$ prihodnosti ni pričakovati razvoja naselja. Zelo verjetno se bo število naseljenih domov še zmanjšalo, število prebivalcev prav tako ali pa bo ostalo približno enako in kulturna pokrajina še v manjši meri "kultivirana". Kar zadeva nasledstvo, se pojavlia tudi 
na Dvorih problem neurejenega lastništva. To pomeni, da sedanii gospodarii niso vedno tudi edini lastniki, ampak jih je več in so razseljeni. Lastniki treh hiš živijo $v$ Trstu in na Dvore zelo redko prihajajo, dve hiši si potomci lastnikov obnavliajo za počitniška bivališča, dve hiši pa sta bili prodani za počitniški hiši priseljencem. Na interes za preživljanje prostega časa in počitnic na Dvorih kaže tudi ena novozgrajena počitniška hiša in pridobivanje dovoljeni še za eno novogradnjo. To sicer oživlja naselje in povečuje interes za obnavljanje domov tudi pri domačinih ter povečuje možnosti za ureditev skupnih površin in infrastrukture, zemliǰšč pa se kljub temu zaraščajo. In slednje predstavlja še večji problem kot vzdrževanje stavbnega sklada. Že sedaj domačini ugotavljajo večji pritisk divjadi in škodo, ki jo povzroča na kmetijskih površinah zaradi zaraslosti okolice, za preživljanje prostega časa pa je zaraščajoča se in težko prehodna pokrajina tudi mani privlačna. Mimo naselja teče označena planinska pot, ki privablia največ pohodnikov spomladi, pogosto so obiskani spodmoli v Steni nad Sočergo, širšo okolico naselja pa $\vee$ jesenskem in zimskem času najbolj obiskujejo lovci. Na spremembe, ki jih je naselje doživelo v zadnjem desetletju, nastanek državne meje ni pomembneje vplival. Že pred njenim nastankom so bile in ostajajo najpomembnejše sorodstvene vezi, kar tri "neveste" so se namreč priselile iz Hrvaške Istre, prekomejno zaposlovanje in oskrba pa sta postopoma izgubljala pomen že pred letom 1991. To je posledica gospodarske nerazvitosti hrvaškega obmejnega dela Istre ter zaposlitvene in oskrbne navezanosti na Koper. Domačini meje ne občutijo kot oviro v prekomejnem povezovanju; tako še vedno uporabliajo "bližnjico" do Mlinov, tu je tudi "neobstoječe" postajališče avtobusa Buzet-Trst in prevoz blaga zaenkrat ni oviran. Domačini mejo pogosto prehajajo zaradi obiskovanja sorodnikov in prireditev, poleti ( $v$ času počitnic) pa tudi zaradi obiskovanja kopaliških krajev v Hrvaški Istri.

\section{Literatura}

Kocjančič, K., B. Bratovž-Ježek idr., 1997: Slovenska Istra, Čičarija, Brkini in Kras, planinski vodnik, Planinska založba Slovenije, Ljubljana.

Krajevni leksikon Slovenije, DZS, Ljubljana 1995.

Kunaver, J., D. Ogrin, 1993: Spodmoli v stenah kraškega roba, Annales 3/93, Koper.

Ogrin, D., 1995: Podnebje Slovenske Istre. Knjižnica Annales 11, Koper. 
Popis prebivalstva in gospodinjstev R Slovenije 1991, Urad RS za statistiko, Ljubliana.

Slovstveni in kulturnozgodovinski vodnik, IV. Notranjska, Kras in južna Primorska. 1998, Zavod RS za šolstvo, Ljubljana.

Temelina topografska karta 1: 25 000, Sočerga, MOP - Geodetska uprava R Slovenije, 1995.

Tomšič, M., R, Šiškovič, S. Žitko, M. Knez, I. Maher, 1999, Na obrobju Movraške vale, Primorske novice, Koper.

\title{
GEOGRAFSKA PROBLEMATIKA OBMEJNEGA NASELJA DVORI PRI MOVRAŽU
}

\begin{abstract}
Summary
Settlement Dvori is a smaller settlement near the border alike to many other settlements in the central Slovene Istra. The settlement is $12 \mathrm{~km}$ far from the nearest supplying settlement Gračišče and more than $20 \mathrm{~km}$ from Koper. Regarding supply and employment, the inhabitants of Dvori were in the past more connected to Buzet, which is $7 \mathrm{~km}$ far off, but nowadays the only connection are their relatives living in Croatian Istra. Dvori are characterised by ageing and decreasing number of inhabitants. During the years 1954-61 the number of inhabitants decreased for one half mostly due to moving away of young people however further decrease of the number of inhabitants results from dying. In the beginning of sixties moving away was the consequence of development of coastal cities and industry of this area, which attracted big quantities of labour resources from the central Istra. Also weddings are representing an important reason for moving away. So there were quite a number of households left without successors or with successors, which did not have any children. Nowadays this situation is reflecting in nearly one half of empty houses and the number is going to be even bigger in the future. Four households do not have any successors. There are 21 inhabitants in Dvori, two thirds of which are older than 50 years and only one young family with a child. Most active inhabitants are employed in Koper and three women are employed in Trieste illegally. Agriculture used to be an important source for survival of numerous families but has stagnated during the last years and nowadays it's
\end{abstract}


only purpose is own supply of the families. In the past all households possessed livestock and there was a lot of cultivable land, in spite of natural conditions being less favourable. Nowadays only bigger plain surfaces are not overgrown, smaller plain surfaces near houses and pastures, situated on the slopes, are overgrown with forest of no economic value. Only one household is still breeding cattle and three households are cultivating the land for production of cereals, potatoes and grapes. Due to unfavourable structure of population the settlement is not expected to become more developed also in the future and consequently cultural landscape will be even less "cultivated". Recently descendants of the inhabitants, moved away, are showing bigger interest in spending their spare time in Dvori and in refitting the abandoned houses, and two houses were also sold to "immigrants". As a result the settlement is revived however the land is still overgrowing. Establishment of the state border had no considerate influence on changes occurred in the settlement during the last ten years. Like during the time prior to its establishment, also today relationships among relatives are the most important, since three brides came from Croatian Istra, and the meaning of employment and supply on other side of the border was decreasing also before 1991. This is the result of economic undevelopment of the Croatian border part of Istra as well as connection with Koper, regarding employment and supply. Domestic inhabitants are not considering the border as some kind of obstacle for across-the-border relations and they usually cross the same with the intention of visiting relatives or some entertainment, and in summer time (during the holiday season) also visiting watering places in Croatian Istra. 